\title{
Communication strategy of the Communication and Informatics Department of Payakumbuh in disseminating Covid-19 information in March - August 2021
}

\author{
Sabrina Rahma Utami ${ }^{1 *}$, Pitoyo ${ }^{2}$ \\ ${ }^{1,2}$ Department of Communication Science, Universitas Gunadarma \\ Corresponding author, email: sabrinaru367@gmail.com
}

\begin{abstract}
Article History
Received: 05/07/2021

Revised:13/07/2021

Accepted: 16/07/2021

Published: $30 / 07 / 2021$
\end{abstract}

\begin{abstract}
The Covid-19 pandemic is a situation that requires proper handling so that it does not spread further. Dissemination of Covid-19 information is one of the steps taken by The Communication and Informatics Department of Payakumbuh (Diskominfo) to increase public participation by providing knowledge and changing people's attitudes to take steps to prevent Covid-19. This study aims to determine the form of the communication strategy of The Communication and Informatics Department of Payakumbuh in disseminating information on Covid-19 with supporting factors and inhibiting factors in its implementation. This research uses a qualitative approach with constructivism paradigm. The theory used in this study is the theory of diffusion of innovation. Data collection techniques were carried out through in-depth and semi-structured interviews and observation. The results of the study show that the form of communication strategy is the stages of compiling communicants or communication targets, messages in the dissemination of Covid-19 information, media selection, determining the frequency of information dissemination, the role of communicators, and public response to the dissemination of information on Covid-19. One of the supporting factors in the dissemination of Covid-19 information is that The Communication and Informatics Department of Payakumbuh's public relations officer has understood the use of information and communication technology, thus facilitating the dissemination of Covid-19 information through new media, and one of the inhibiting factors is the lack of coordination at The Communication and Informatics Department of Payakumbuh in managing the website, and the lack of openness of hospital management in Payakumbuh in providing information updates on Covid-19 in Payakumbuh City.
\end{abstract}

Keywords: information dissemination, Covid-19, Payakumbuh City

\section{Introduction}

Covid-19 (Coronavirus-Disease 2019) is a disease caused by a new variant of the Corona virus (Novel corona-virus). Covid-19 spread rapidly to many countries in the world, until now Covid-19 became a pandemic. In Indonesia, the first Covid-19 case was discovered on March 2, 2020, which was announced directly by President Joko Widodo. Until now Covid-19 cases in Indonesia have increased, 
which on August 2, 2021, there have been 3,774,155 people exposed to Covid-19 (Beranda | Covid19.Go.Id, n.d.).

Payakumbuh city is one of the cities in West Sumatra Province, which is also exposed to Covid19. The first case of Covid-19 was found on April 24, 2020, at which time a trader in the central market of Payakumbuh City tested positive for Covid-19. To date (August 12, 2021), positive cases of Covid19 in Payakumbuh City have amounted to 2305 cases. The new situation for the community, to massive news in various media such as television media, online media, to social media, causes the public to experience an over-abundance of information, which is related to the unfiltered information, until the spread of personal data of patients confirmed positive Covid-19 in the community.

Facing the phenomenon in society that is developing related to misperceptions, disinformation, and the amount of hoax and misleading information, it is necessary to disseminate information about Covid-19 as an effort to socialize and educate the public, so that people understand what Covid-19 is and what steps to take the community must do that to remain safe and protected from Covid-19. Dissemination of correct information and good education to convey the message to the public is an effective effort to prevent Covid-19 from spreading wider.

Public information dissemination based on the Regulation of the Ministry of Communication and Informatics Number 17/PER/KOMINFO/03/2009 is an obligation for the Government from the central to the regional levels to carry out reciprocal dissemination of information to the public, whether requested or not, which is conveyed through mass media, as well as other communication media, and community communication institutions. Public information itself based on Law Number 14 of 2008 concerning Openness of Public Information is information that can impact people's lives in the national scope. Information dissemination is an effort to realize the implementation of good governance and encourage public participation in disseminating information. Information dissemination is also the implementation of Public Information Openness, in fulfilling the public's right to obtain credible and easy to access information.

In general, as a policy holder, the Government, in this case Payakumbuh's Government has made various policies to deal with the Covid-19 pandemic that has spread in Payakumbuh City, one of which is by disseminating information on Covid-19. Under Payakumbuh's Government, The Communication and Informatics Department plays a role in disseminating information to the public about Covid-19, providing educational information and sharing Government activities in carrying out the Covid-19 pandemic management program. In disseminating information on Covid-19, a communication strategy 
is needed to effectively disseminate information on Covid-19. So that the public gets sufficient and credible information, and can then bring about a change of attitude in the community to be able to take care of themselves and prevent COVID-19 from spreading more widely through the implementation of health protocols, as well as being a means to straighten out issues, hoaxes, or information that leads to negative opinions circulated in the community. This study aims to identify and analyze the communication strategy of The Communication and Informatics Department of Payakumbuh (Diskominfo) in disseminating information on COVID-19 and identifying and analyzing the supporting and inhibiting factors for the dissemination of Covid-19 information in Payakumbuh City.

\section{Communication Strategy}

Communication strategy serves as a direction for communication planning and communication management in order to achieve the goals that have been agreed upon. The communication strategy must describe how its operations practically must be carried out, where the approach can change at any time depending on the situation and circumstances (Effendy, 2009). Communication strategy is part of the public relations strategy that must be owned by public relations to improve performance within an organization (R. Wulandari et al., 2019). A good strategy is needed to increase communicant segmentation and take advantage of digital technology such as smartphones and social media applications (Y. Wulandari \& Wahyudin, 2021).

\section{Diffusion of innovation Theory}

Diffusion of innovation is a process of spreading new ideas or ideas conveyed through channels within a certain period of time as an effort to social change the unit of society. Diffusion is a process by which an innovation is communicated through specific channels over time among members of a social system. Diffusion is part of social change, which is defined as a process, where there is a change in the structure and function of the social system. When a new idea is created, diffused, adopted, or rejected, there are several consequences: social change (Rogers, 2003).

\section{Method}


The approach in this research is qualitative. Qualitative research intends to describe the phenomenon as deeply as possible through collecting data as deep as possible (Kriyantono, 2014). In this study, the paradigm used is the constructivist paradigm. In the constructivist paradigm, researchers can position themselves as subjects to explore and understand the real object (Surokim et al., 2016). In this study, the sampling technique used is the purposive sampling technique. This technique includes selecting people based on specific criteria made by the author based on the research objectives (Kriyantono, 2014). With purposive sampling technique, informants can be selected in this study consisting the Head of Public Relations Division of The Communication and Informatics Department of Payakumbuh (Diskominfo), 1 (one) The Communication and Informatics Department of Payakumbuh (Diskominfo) journalist, and 3 (three) Payakumbuh residents.

The method of collecting data is through observation and semi-structured interviews and in-depth interviews. Data analysis was carried out using the Miles \& Huberman (1994) method: data reduction, data presentation, conclusion drawing, and verification. In this study, to test the validity or validity of the data, triangulation analysis was carried out, that is analyzing the subject's answers by examining the truth of the data pragmatically. Meanwhile, the triangulation analysis used is source triangulation, which compares or checks the degree of trust in information obtained from different informants (Kriyantono, 2014).

\section{Discussion}

The Communication and Informatics Department of Payakumbuh is one of the regional apparatus organizations (OPD) whose task is to assist the Mayor in carrying out all regional government activities related to the field of communication and informatics. The Covid-19 pandemic is a situation that the Government and society have never faced systematically before. This unexpected situation created confusion and gave a real shock to the community (Muktiyo, 2020). The Covid-19 pandemic itself is categorized as an extraordinary event that has an impact on public health and has a socio-economic impact on the community.

To overcome this, Payakumbuh's Government, took preventive steps by focusing on various government activities for handling, one of which was through the dissemination of Covid-19 information by The Communication and Informatics Department of Payakumbuh. Dissemination of Covid-19 information is carried out to increase public knowledge about Covid-19, so that people get credible sources of information, avoid hoaxes, and shape changes in attitudes in preventing the spread of Covid- 
19. Based on the researcher's observations on the Covid-19 Information dissemination activity of The Communication and Informatics Department of Payakumbuh (Diskominfo), there are several stages of developing a communication strategy, such as:

\section{Communicate/ Target}

The Communication and Informatics Department of Payakumbuh (Diskominfo) as the regional apparatus organizations tasked with disseminating information to the public, must provide information services to the entire community, without exception.

Dissemination of information on Covid-19 is aimed at the entire community, and is distributed through various media, which one of them is internet. Meanwhile, the results of this study indicate that some people in Payakumbuh City, which is the communication target, have utilized the use of the internet to access information about Covid-19. However, there are still some that have not been reached by the internet, due to limited facilities and lack of understanding of the usefulness of the internet.

\section{Message in Covid-19 Information Dissemination}

Informative messages are intended to provide a description of facts and data, which are then concluded and the communicant can make their own decisions (Suryanto, 2015). Messages in the dissemination of Covid-19 information are also carried out to educate and persuade the public, as a form of prevention of the spread of Covid-19, so the message in the dissemination of information on Covid19 consists of three things, which is: informative, persuasive, and instructive/coercive.

Informative messages that were disseminated contained information such as the spread of Covid19 in Payakumbuh City, information about Covid-19 symptoms, explanations of herd immunity, information about the status of the Covid-19 distribution zone, to information related to the activities of Payakumbuh's Government in dealing with the pandemic Covid-19.

A persuasive message is a message that aims to persuade the recipient to accept and act according the instructions in the message conveyed, but this recommendation is not coercive. In the Covid-19 pandemic situation, several recommendations must be followed so that the community remains protected from Covid-19, such as recommendations for implementing health protocols.

Instructive messages are coercive messages and are accompanied by sanctions if they are not followed.

Payakumbuh Government establishes a firm policy, and conveyed by The Communication and Informatics Department of Payakumbuh (Diskominfo) in an information release, which gives orders for the public not to violate the rules that have been established for the prevention of Covid-19. 


\section{Media Selection}

Media is a channel for conveying or communicating messages. During the dissemination of information on Covid-19 carried out by The Communication and Informatics Department of Payakumbuh (Diskominfo), several communication media used are the use of Payakumbuh government websites (http://berita.payakumbuhkota.go.id and http://covid19.payakumbuhkota.go.id), as a medium for track the Covid-19 situation in Payakumbuh and inform the public how Payakumbuh Government handle the Covid-19 pandemic. Then, The Communication and Informatics Department of Payakumbuh (Diskominfo) also uses social media as a medium for disseminating information of Covid-19, such as Facebook (Payakumbuh Government Facebook https://web.facebook.com/pemkopayakumbuh/, and The Communication and Informatics Department of Payakumbuh (Diskominfo) Facebook account https://web.facebook.com/diskominfokotapayakumbuh), Instagram (Payakumbuh Government Instagram https://www.instagram.com/pemkopayakumbuh, and the communication and informatics $\begin{array}{lllll}\text { department } & \text { (Diskominfo) } & \text { Instagram account }\end{array}$ https://www.instagram.com/diskominfo_payakumbuh/), Twitter (https://twitter.com/pemkopyk), YouTube (https://youtube.com/pemkopayakumbuh), WhatsApp instant messaging application, and Uda Kopay application on Android devices. Uda Kopay application, which stands for Payakumbuh City Update (Update Kota Payakumbuh), is an application formed by the communication and informatics department of Payakumbuh (Diskominfo) as an innovation to disseminate information on Covid-19 and facilitate data collection regarding Covid-19. Uda Kopay application is an innovation that indicates that the Payakumbuh Government has developed digital public information services that can facilitate the dissemination of Covid-19 information.

\section{Frequency of Information Dissemination}

In disseminating information, so that the message can reach the communicant effectively, it is necessary to pay attention to the frequency of the information is delivery. Covid-19 information is disseminated daily through updates on Covid-19 outgrowth on various media. However, there are times when the Government sees at the situation and conditions in the community. So that in certain situations, The Communication and Informatics Department of Payakumbuh (Diskominfo) does not update the dissemination of Covid-19 information every day.

\section{Role of Communicator/ Information Source}


Sources in communication are the basis for disseminating information in strengthening the message being disseminated. In this case, sources can be individuals, organizations or institutions, information media, and others. In disseminating information on Covid-19 by The Communication and Informatics Department of Payakumbuh, information was obtained from several sources. The first source of Covid-19 information is from the government level.

Next, the Head of Public Health Department of Payakumbuh is a regional apparatus organization that is a source of Covid-19 information disseminated by Payakumbuh Government. As a regional apparatus organizations that is the leading sector in dealing with public health, The Public Health Department of Payakumbuh is a regional apparatus organization that best understands the current pandemic situation, and what steps must be taken in order to deal with Covid-19.

Then, the Public Relations Division of The Communication and Informatics Department of Payakumbuh also saw the issues that developed in the community as a source of disseminated Covid-19 information, by deploying a public relations coverage team to counter issues around Covid-19, which were then made in the form of news releases. Furthermore, Payakumbuh Covid-19 Task Force is also a source of information, because the Covid-19 Task Force is a team specially formed to deal with Covid19 in Payakumbuh City. The Covid-19 Task Force consists of members from several regional apparatus organizations in Payakumbuh City. As a source, the Covid-19 Task Force can provide information from various aspects of handling and developing Covid-19 in Payakumbuh City.

Meanwhile, the communicators include the Head of The Communication and Informatics Department of Payakumbuh, who acts as a spokesperson for Payakumbuh's Covid-19 Task Force, then the Head of Public Health Department of Payakumbuh, dr. Bakhrizal, and public figures, such as the Mayor of Payakumbuh, Deputy Mayor of Payakumbuh, and religious leaders.

\section{Community Response to Covid-19 Information Dissemination in Payakumbuh}

Response is a reaction or feedback resulting from information dissemination activities, which can be in the form of positive, negative, or neutral reactions. The dissemination of information on Covid-19 carried out by Payakumbuh government received various responses from the public. Most people think that the Payakumbuh city government has provided information on Covid-19 optimally and openly. While others, think that Payakumbuh government is not transparent in providing information about the development of Covid-19 in Payakumbuh city. 
In addition, the response from the public to the dissemination of Covid-19 information can also be seen from how changes or actions are taken from the community after the dissemination of Covid-19 information is carried out. One of the informants revealed that information on the development of Covid19 was an innovation or new idea that he received, where after he received the information on Covid-19, there were changes in some of the actions he took, such as starting to implement health protocols, wearing masks and washing hands.

\section{Supporting Factors and Inhibiting Factors of Public Information Disclosure in Dissemination of Covid-19 Information in Payakumbuh}

The first supporting factor in the dissemination of Covid-19 information in Payakumbuh is the formation of an understanding of the use of information technology by employees of the Public Relations Division of The Communication and Informatics Department of Payakumbuh (Diskominfo). In order for the dissemination of Covid-19 information to run smoothly and effectively, as well as to support the interactivity of The Communication and Informatics Department of Payakumbuh (Diskominfo) to the public, public relations employees who have understood the use of information and communication technology have a good impact on the Covid-19 information dissemination process.

The second supporting factor is the convenience for the Public Relations Division of the communication and informatics department of Payakumbuh (Diskominfo) in coordinating with all Regional Apparatus Organizations, because The Communication and Informatics Department of Payakumbuh (Diskominfo) and other regional apparatus organization are carrying out duties from the Government.

The third supporting factor for the communication and informatics department of Payakumbuh (Diskominfo) in the further dissemination of Covid-19 information is the existence of a credible source of information within Payakumbuh Government.

Furthermore, the inhibiting factors or factor that can hinder the dissemination of Covid-19 information in Payakumbuh, the first is the low public response to the implementation of Public Information Disclosure. In 2020, Payakumbuh's public information management officer (PPID) did not receive a single request for public information (PPID Payakumbuh City Government, 2021). This of course causes the public's right to know information is not utilized optimally. 
The second inhibiting factor is the negative perception of people who do not believe in the existence of Covid-19. This kind of public perception makes it difficult for the Government to persuade the public to implement health protocols.

The third inhibiting factor is the negative response given by the community when information on Covid-19 is disseminated. This has resulted in some media journalists in Payakumbuh being reluctant to release news containing information about Covid-19. The fourth inhibiting factor is the ignorance of the Payakumbuh Government in measuring the extent to which the spread of Covid-19 information is carried out.

The fifth inhibiting factor for disseminating Covid-19 information in Payakumbuh, is the existence of miscoordination between Divisions at The Communication and Informatics Department of Payakumbuh (Diskominfo) in managing the website of Payakumbuh Government. The Head of Public Relations of The Communication and Informatics Department of Payakumbuh (Diskominfo) also explained why the Payakumbuh Government's website is difficult to update, because local officials in apparatus organization in Payakumbuh are not accustomed to using websites to upload public information, but using social media. So that the existing website seems abandoned at first.

The sixth inhibiting factor for the dissemination of Covid-19 information in Payakumbuh is the lack of openness of health facilities such as hospitals in providing updated information about Covid-19. Based on the results of an interview with a journalist from at The Communication and Informatics Department of Payakumbuh (Diskominfo), it is known that hospitals are often not willing to provide information on the development of Covid-19, on the grounds that patient data cannot be published. Even though at The Communication and Informatics Department of Payakumbuh (Diskominfo) journalists have explained that they also have a news writing code of ethics not to disclose patient personal data, the hospital is still not open in providing information, and diverts to request information from other institutions.

The seventh inhibiting factor for the dissemination of Covid-19 information in Payakumbuh is the limited skilled and professional human resources. Based on the report from the Strategic Plan of at the communication and informatics department of Payakumbuh (Diskominfo) for 2017-2022, and the observations researchers, in the Public Relations Division of The Communication and Informatics Department of Payakumbuh (Diskominfo), there is a shortage of technical personnel in creating Covid19 information content, there are only two (2) employees who can create visual information content in the Public Relations Division. 
In relation to the theory of diffusion of innovation used in this study, it can be analyzed that there have been social and technological changes in society. Digital technology is growing, requiring the Government to be able to take advantage of the use of technology such as new media or the internet in managing and disseminating information to the public.

The use of information and communication technology in implementing public information disclosure by the Government can encourage transparency and accountability, which increases public confidence in the Government and any policies made. In addition, the use of this technology is also an effort to realize good governance. New media such as the internet is an innovation that the Government can adopt in order to provide information to the public to be quickly and easily accessible to the public anytime and anywhere.

The theory of diffusion of innovation in its development explains that the role of communicators influences attitudes and behavior in society. In addition, it is also explained that the mass media can be very influential in disseminating innovations in the form of new ideas or ideas. Primarily if the new idea is conveyed again by being re-communicated by influential figures in the community. Despite the diffusion of innovation, it can directly affect the communicant.

The application of the diffusion of innovation in this study can be seen that The Communication and Informatics Department of Payakumbuh (Diskominfo) is the source in disseminating messages with the diffusion of innovation. So that the dissemination of information on Covid-19 becomes a new idea that is accepted by the public. Dissemination of Covid-19 information is carried out by creating Covid19 information content, so that people get knowledge about Covid-19, so they can avoid hoax news, and formed changes in attitudes and behavior in the community to be able to prevent the spread of Covid-19 from getting wider. This information content is disseminated through several media, some of which are new media consisting of a website, social media, WhatsApp application, and Uda Kopay application; an application designed by The Communication and Informatics Department of Payakumbuh (Diskominfo) specifically to provide information on Covid-19 developments.

In this case, the innovation of the strategy applied is the use of communication media, which can disseminate information to the public without any limitations of space and time. Through the use of new media to disseminate Covid-19 information, the public can provide their response, which encourages public participation in the disclosure of public information in the Payakumbuh Government. 
During the dissemination of Covid-19 information, there are communicators who are experts in their fields and the participation of influential public figures, such as mayors, deputy mayors, heads of public health department, and religious leaders. The implementation of the innovation carried out by The Communication and Informatics Department of Payakumbuh (Diskominfo) is a preventive measure against Covid-19 and an effort to encourage people to use digital media as a source of information.

\section{Conclusion}

Based on the description of the problem background, objectives, theoretical basis, methods, and research results, the conclusions of this study are as follows:

1. The public relations department of The Communication and Informatics Departmentof Payakumbuh implements a communication strategy in the dissemination of Covid-19 information, with the stages of strategy formulation: 1) provide Covid-19 information to the community, without perception; 2) Messages contained in the Covid-19 information dissemination, consist of informative messages, persuasive messages, and instructive or coercive messages ; 3) The media used as a channel for disseminating information about Covid-19 through new media are websites, social media Facebook, Instagram, Twitter, YouTube, instant messaging application WhatsApp, and the Uda Kopay application (Update Kota Payakumbuh) designed by The Communication and Informatics Department of Payakumbuh; 4) The frequency of dissemination of Covid-19 information is carried out every day; 5) The sources of information are divided into two, namely hierarchically originating from the central Government and provincial governments, then issues that are developing by the community. Communicators who play a role have credibility and attractiveness, such as experts in their fields as well as community leaders; 6) The response of some people to respond that the dissemination of information on Covid-19 has been carried out by the Payakumbuh government optimally and transparently. However, the other some people still think that the Government is not open to providing public information.

2. The supporting factors for the communication strategy of The Communication and Informatics Department of Payakumbuh in disseminating information about COVID-19 are: 1) The understanding of The Communication and Informatics Department of Payakumbuh's public relations officer has formed in using information and communication technology; 2) The convenience of The Communication and Informatics Department of Payakumbuh to obtain information on COVID-19 because coordination with 
all regional apparatus organizations has been formed; 3) The Communication and Informatics Department of Payakumbuh already has credible sources in conveying the development of information.

3. The inhibiting factors for the communication strategy of the Payakumbuh City Communication and Information Office in disseminating information about COVID-19 are: 1) The low level of requests for information requests from the people of Payakumbuh ; 2) There are people who have an understanding of not believing in Covid-19; 3) There are people who respond negatively to Covid-19 information that is disseminated, so that some media journalists are reluctant to release Covid-19 information; 4) The ignorance of the Payakumbuh Government in measuring the extent to which the spread of Covid-19 information is carried out; 5)There is a miscoordination in the management of the website at The Communication and Informatics Department of Payakumbuh, and regional officials are not accustomed to publishing information through websites but through social media; 6) The management of Hospital in Payakumbuh are less open in providing updates on Covid-19 information to journalists; 7) Limited human resources or technical personnel in content creation and social media management in the public relations sector of The Communication and Informatics Department of Payakumbuh.

\section{References}

Beranda | Covid19.go.id. (n.d.). Retrieved April 23, 2021, from https://covid19.go.id/

Effendy, O. U. (2009). Ilmu Komunikasi: Teori dan Praktek. PT Remaja Rosdakarya.

Informasi Penanganan Covid19. (n.d.). Retrieved August 24, 2021, from https://covid19.payakumbuhkota.go.id/

Kasus Pertama di Payakumbuh, Pedagang Pasar Positif Corona. (n.d.). Retrieved March 17, 2021, from https://langgam.id/kasus-pertama-di-payakumbuh-pedagang-pasar-positif-corona/

Kriyantono, R. (2014). Teknik Praktis Riset Komunikasi. Penerbit Kencana.

Miles, M. B., \& Huberman, M. (1994). Qualitative Data Analysis. SAGE Publications, Inc.

Muktiyo, W. (2020). STRATEGI KOMUNIKASI DAN DISEMINASI INFORMASI PUBLIK PEMERINTAH TERKAIT PENANGGULANGAN PANDEMI COVID-19 (I. Cawidu, M. J. Indarto, P. Hadi, D. Y. Lestari, V. R. Hapsari, F. L. Warauw, T. Rauf, D. Rahmarini, T. Ghaida, C. I. Octama, \& Nurjiyanto (Eds.)). Halaman Moeka Publishing.

PPID Pemerintah Kota Payakumbuh. (2021). Laporan Tahunan PPID 2020. 
Rogers, E. M. (2003). Diffusion of Innovations, 5th Edition. Free Press. https://books.google.co.id/books?id=9U1K5LjUOwEC

Surokim, Rakhmawati, Y., Suratnoaji, C., Wahyudi, M., Handaka, T., Dirtiningsih, B. E., Julijanti, D. M., Rachmawati, F. N., Kurniasari, N. D., Trisilowati, D., Suryandari, N., Cholil, H. A., Quraisyin, D., Moertijoso, B., Rachmad, T. H., Arifin, S., Rozi, F., \& Camelia, A. (2016). Riset Komunikasi Strategi Praktis Bagi Peneliti Pemula (Surokim (Ed.)). Pusat Kajian Komunikasi Publik Prodi Ilmu Komunikasi, FISIB-UTM \& Aspikom Jawa Timur.

Suryanto. (2015). Pengantar Ilmu Komunikasi. CV Pustaka Setia.

Wulandari, R., Prayudi, \& Afifi, S. (2019). CRISIS MANAGEMENT STRATEGY OF TEGAL CITY PUBLIC RELATIONS. The Indonesian Journal of Communication Studies, 12(1), 15-27. https://doi.org/10.14434/do.v12i1.27756

Wulandari, Y., \& Wahyudin, A. (2021). Strategic analysis of "Lintas Denpasar Pagi" radio program at Radio Republik Indonesia Denpasar in serving public interest. The Indonesian Journal of Communication Studies, 14(32), 31-43. https://doi.org/https://doi.org/10.31315/ijcs.v14i1.5056 